\title{
Modification of Cable Insulation Characteristics Using Nanocomposites for the Nuclear Power Plant
}

- El-Sayed Soliman A. Said Department of Electrical Engineering, Faculty of Engineering at Al-Azhar University, Cairo, Egypt ORCID: https://orcid.org/0000-0001-9973-1820

- El Saeed Abdul El-Aziz Othman Department of Electrical Engineering, Faculty of Engineering at Al-Azhar University, Cairo, Egypt ORCID:https://orcid.org/0000-0002-3719-3112

- Mohamed Reda Ezz-eldin Egyptian Nuclear and Radiological Regulatory Authority (ENNRA), Cairo, Egypt ORCID:https://orcid.org/0000-0003-1858-748X

- Howayda Galal A.M Taha Egyptian Nuclear and Radiological Regulatory Authority (ENNRA), Cairo, Egypt ORCID:https://orcid.org/0000-001-9124-6548

- Walaa Abd-Elmonem El-kattan Egyptian Nuclear and Radiological Regulatory Authority (ENNRA), Cairo, Egypt ORCID:https://orcid.org/0000-0002-9482-0194

\begin{abstract}
Nowadays, the nuclear power plant (NPP) lifetime can be extended to 80 years. This allows recommending the modifications in some properties of cross-linked polyethylene (XLPE) cable insulation. This work is laboratory implementation of nanofillers such as silicon dioxide $\left(\mathrm{SiO}_{2}\right)$ and clay to enhance cable insulation. The volume resistivity, capacitance, dielectric loss, tensile strength and elongation properties were tested and measured for the nanosized samples. Furthermore, these measurements were carried out for modified XLPE/ $\mathrm{SiO}_{2}$ and XLPE/clay samples with additive concentration of 1, 2.5, 4 and 5 weight percentage (wt. \%). The officially documented results showed much better cable electrical insulation and mechanical profile. $205 \%$ and $189 \%$ improvement in volume resistivity was observed for XLPE/SiO, and XLPE/clay, respectively. The analytical calculations were in agreement with the experimental results.
\end{abstract}

Key word s:XLPE, nanofillers, cable insulation, electrical and mechanical properties.

(ㄷ) El-Sayed Soliman A. Said, El Saeed Abdul El-Aziz Othman, Mohamed Reda Ezz-eldin, Howayda Galal A.M Taha, Walaa Abd-Elmonem El-kattan, 2019

$\mathrm{T}$ The nuclear power plant lifetime ranges from 40 to 60 years. The federal regulators are considering long-term operation of these nuclear power plant licenses to be 80 years [1, 2 and 3]. This can only occur with some developments in polymeric cable insulation, which can be achieved through combining the nanofillers with the polymer of cables. There were many types of nanofillers, which are used in combination with polymers such as silicon dioxide $\left(\mathrm{SiO}_{2}\right)$, aluminum dioxide $\left(\mathrm{Al}_{2} \mathrm{O}_{3}\right)$ and titanium dioxide $\left(\mathrm{TiO}_{2}\right)$ [4, 5 and 6]. This combination provided new materials called polymer nano-composites (PNC)
[7 and 8]. PNCs add several advantages such as: improving the specific properties and electrical properties of cable insulators, transformers and power capacitors. That plays an important role in reducing the cost of industry and extends the lifetime of cables [6]. As an example, the resistance of nanocomposites to partial discharges and electric treeing enables the design of new insulation systems with enhanced electrical breakdown strength. In addition to electrical properties, mechanical strength and thermal conductivity play an important role in selected applications such as insulation systems of large 
electrical machines [9]. In addition, permittivity and dissipation factor should be as low as possible for electrical insulation whilst for capacitors; loss factor should be as high as possible. Flame retardancy is a property required for cable insulation used in the radiation field in tunnels, while tracking resistance is very important for outdoor insulators [10].

On the other hand, nanofillers have a prominent feature of extended surface area, which changes the structure and behavior of the polymer that makes the atoms increased on the surface, and thus, reduces the internal space charge and energy. The interaction region between the polymer chains and the nano particle is the cause of trapping process. Therefore, nanofillers are responsible for carrying charges to the interaction regions. Thus, internal charges are reduced from the composite materials. When the interfacial interaction region between the nanofillers and the base polymer matrix is strong, the composite material tends to be reinforced, thus this material is improved and enhanced [11].

Many scientific research groups were interested in enhancing the electrical properties of insulating cables by functionalizing the surface of nanoparticles. From them, Peng et al. [12] had found that LDPE/MgO interface showed significant effect on electrical properties of nanocomposites upon the addition of functionalized $\mathrm{MgO}$ nanoparticles to LDPE, and this is due to the trapping of the free space charges, which in turn enhanced DC breakdown strength. Roy, Nelson et al. [13] observed that incorporation of $\mathrm{SiO}_{2}$ nanoparticles into XLPE significantly increased the dielectric strength compared to the incorporation of microparticles, and their values were compared with the base polymer, a dramatic increase in breakdown strength was observed in the case of untreated nanocomposites compared to microcomposites. However, the largest increase was observed for the vinylsilane treated $\mathrm{SiO}_{2} / \mathrm{XLPE}$ composites at $25^{\circ} \mathrm{C}$ that maintained to increase their values at elevated temperature of $80^{\circ} \mathrm{C}$. For all the analyzed samples, the Weibull shape parameter $(\beta)$ increased at $80{ }^{\circ} \mathrm{C}$ due to an increase in free volume with temperature.

Roy et al. Khodaparast et al. [14] studied the impact of functionalized $\mathrm{SiO}_{2}$ on dielectric behavior of polyvinylidene fluoride (PVDF)/ $\mathrm{TiO}_{2}$ nanocomposite. The obtained data demonstrated that an appropriate silane coupling agent is essential in enhancing the nanoparticles dispersion, and hence in strengthening the polymer-particle interface. In addition, dielectric permittivity of the prepared samples was decreased with increasing concentration of functionalized $\mathrm{TiO}_{2}$ nanoparticles.

The aim of this study is to investigate the effect of Nanofillers such as Silicon Dioxide $\left(\mathrm{SiO}_{2}\right)$ and Clay to enhance cable insulation. The electrical characteristics to be measured are volume resistivity, capacitance, dielectric loss, and the mechanical characteristics are tensile strength and elongation properties, since they reveal information on the effectiveness of a material as an insulator [15]. Thus, it is very important to study how these parameters vary in materials at different frequencies. Furthermore, it is very important to study the effect of nanoparticles contents on the properties of the fabricated nanocomposites. Thus, this study involves the synthesis of XLPE/SiO 2 and XLPE/ Clay nanocomposites with different loadings of $\left(\mathrm{SiO}_{2}\right)$ and Clay nanoparticles $(1,2.5,4$ and 5 wt. \%) compared to that of unfilled XLPE.

\section{Reliability of the cables operating in nuclear power plant}

NPP is usually estimated by the condition monitoring tests followed by accelerated aging. This approach is necessary, as cable insulations and jackets, gradually predominantly degrade with increasing service time due to exposure to two adverse stressors associated with gamma radiation and elevated temperatures. At present, different procedures were implemented for the initial and on-going qualifications of NPP cables [16].

\section{Materials platform}

XLPE cable can be considered the best one for transmission and distribution cables due to its excellent electrical and physical properties [17 and 18]. Low Density of Polyethylene (LDPE) is used as a commercially available material supplied from El-Sewedy Electric Egyplast of Egypt. LDPE was mixed with Luperox 231 M90 component for cross-linking, and blend with 
IRGANOX B 225 component to provide long term thermal stability and add IRGANOX PS 802 component for a heat stabilizer in combination with a phenolic antioxidant.

In this work, nano-silica $\mathrm{SiO}_{2}$ such as (AEROSIL 300) and nano-clay such as (CLOISITE) were used for mixed XLPE cable insulation to improve. However, the largest increase was observed and extend life time of cable insulations by enhancing the electrical and mechanical properties. Yan et al. Wei et al. [19-20] show that the values of weight loss, char index, flame spread rating, heat release rate, total heat release, smoke production rate, total smoke release and specific optical density of the coatings are remarkably decreased with the introduction of nano-silica, which is due to the formation of a compact and intumescent char layer during combustion.

The flame retardant clay nanocomposites were incorporated into polymer matrix. The flame retardant efficiency is improved due to the fact that the clay layers were almost exfoliated in polymer matrix [21]. Generally, the dispersions of clay are due to the previous dispersion of clay in flame retardants and the combination of both flame retardants and clays could improve the flame retardant efficiency. Thus, clay nanocomposites can be used as novel halogen-free flame retardant agents in many general polymer materials [22].

CLOISITE additives consist of organically modified layered magnesium aluminum silicate platelets [23-24]. $\mathrm{SiO}_{2}$ nanoparticles are provided as fumed silica with specific surface area of $380 \mathrm{~m}^{2} \mathrm{~g}^{-1}$ and particle diameter range of 3-15 $\mathrm{nm}$ [25]. These two types of nano materials are mixed with the insulation of the cables separately in the following proportions and make up $1 \%, 2.5 \%, 4 \%$, and 5 wt. $\%$.

\section{Samples preparation}

1. All ingredients and the polymer material are blended and compounded in pilot extruder planning (Figure 1). Extruder supplier has screw diameter of $45 \mathrm{~mm}$ for squeezing the ingredients with heating to $120^{\circ} \mathrm{C}$ to integrate the components homogenously. The obtained granules have been cooled by cold water, and then dried by hot air at $55-65^{\circ} \mathrm{C}$.

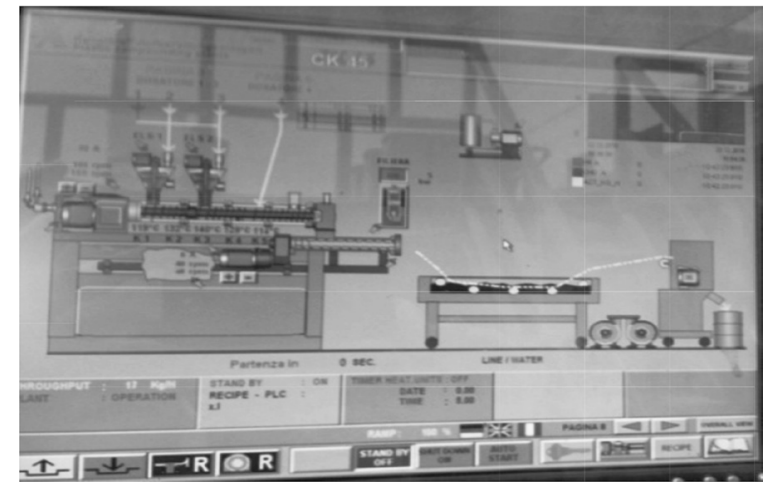

Figure 1. The pilot extruder planning for blended and compounded polymer materials

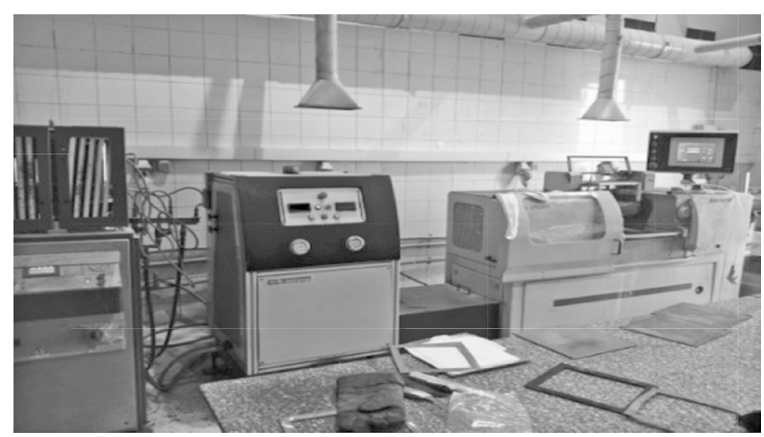

Figure 2 The hot press instrument for sheet

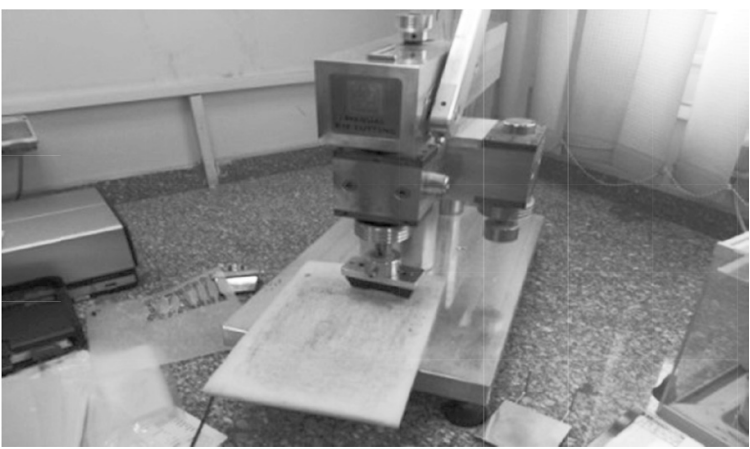

Figure 3 Dumbbell shape cutter instrument according to ISO-527

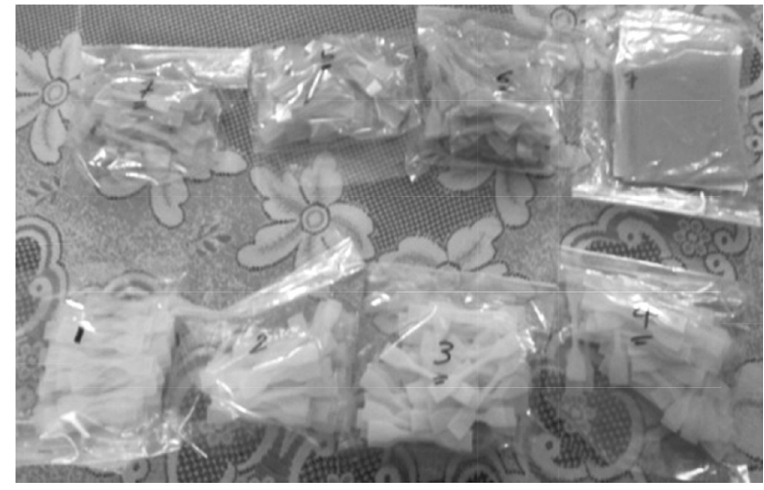

Figure 4 Cubic shape samples with the dimension of $10 \times 10 \mathrm{~cm}$ 
2. The obtained compound granules were inserted into hot press instrument (Figure 2) to be molded at $180^{\circ} \mathrm{C}$ for 15 minutes and then cooled to $60^{\circ} \mathrm{C}$ under pressure of 300 Pascal $(\mathrm{Pa})$ to obtain press-molded sheets. Sheet thicknesses is $1-2 \mathrm{~mm}$ with dimension of $20 \times 20 \mathrm{~cm}$.

3. These press molded sheets were cut into two types:

a) Dumbbell shape samples by using Dumbbell shape cutter instrument (Figure 3) according to ISO-527 for testing of tensile strength and elongation.

b) Cubic shape samples with the dimension of $10 \times 10 \mathrm{~cm}$ and $100 \mathrm{~mm}$ diameter (Figure 4) for testing of electrical properties.

All the experimental measurements were carried out at El-Sewedy, Electric Egyplast Laboratories in Egypt.

\section{Measurements \\ Electrical Measurements. Volume resistivity}

Volume resistance was measured by ASTM-D275 volume resistivity tester (Figure 5) at room temperature. The press-molded sheets were inserted

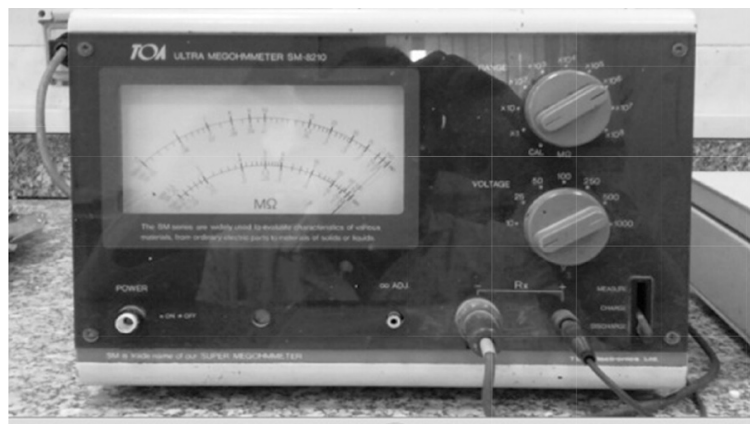

Figure 5 ASTM-D275 volume resistivity tester

into the sample holder and charged for $1 \mathrm{~min}$ at $500 \mathrm{kV}$. The results are the average measurements of five different specimens for each sample.

\section{Capacitance and Dielectric Loss}

The capacitance and dielectric properties of the materials were measured at room temperature by ASTM-D150 capacitance tester (Figure 6). There were two electrodes deposited

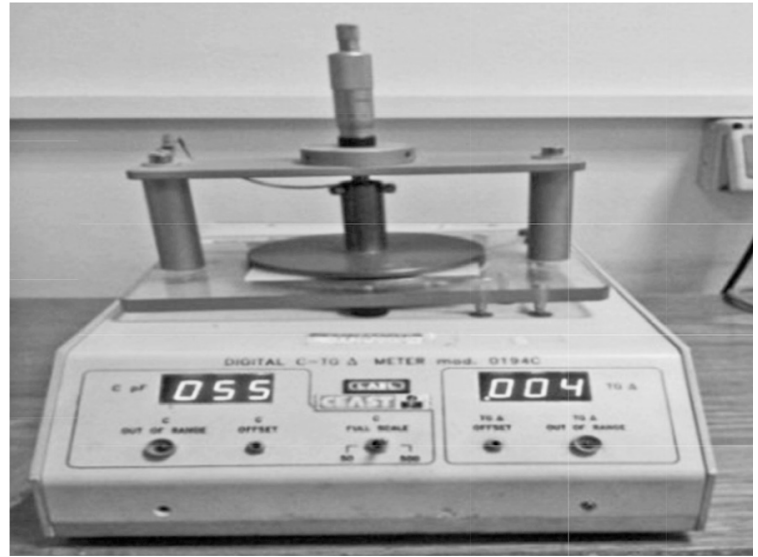

Figure 6 Capacitance tester (ASTM-D150) with two sputtered electrodes

into the both surfaces of the specimens by sputtering, and the diameter of sputtered electrodes is $7 \mathrm{~cm}$. The results are the average measurements of five different specimens.

\section{Mechanical Measurements. Tensile Strength and Elongation}

Tensile strength and elongation tests were performed according a standard mechanical measurement tester (BS EN 60811) (Figure 7). The samples have Dog-bone shapes that were cut in parallel with and perpendicularly to the extrusion direction. All the tests were performed at room temperature and the final results are the average values of five replicated measurements.

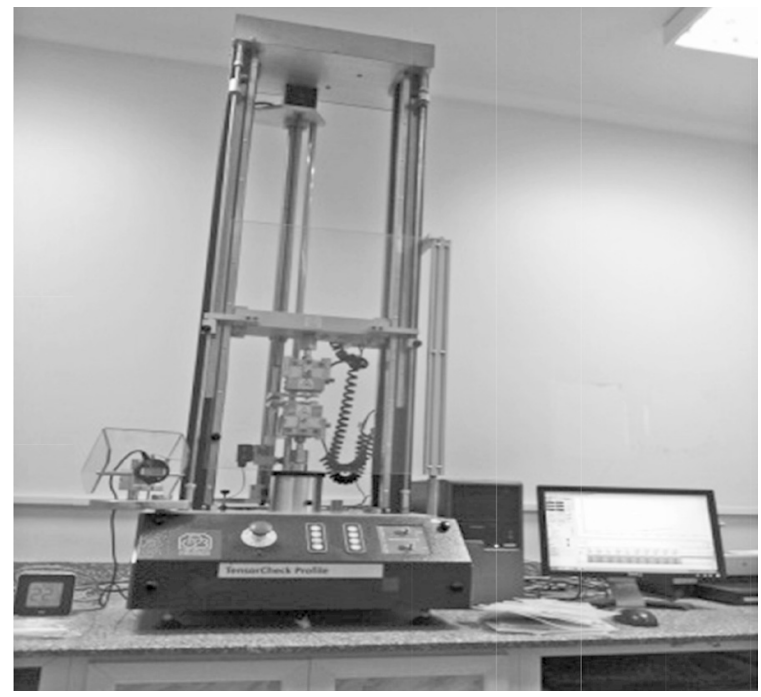

Figure 7 Mechanical measurements tester (BS EN 60811) 


\section{Results}

The results were obtained from both electrical and mechanical measurements. First, the electrical measurements that included volume resistivity, insulation resistance, electric capacitance and dielectric constant, while the mechanical measurements included tensile strength and elongation.

\section{Electrical Measurements. Volume} Resistivity and Insulation Resistance

Fig. 8 demonstrates the comparison of pure and modified XLPE with $\mathrm{SiO}_{2}$ \& clay nanomaterials. XLPE/Clay values in this figure that demonstrates volume resistivity of the modified cable with $1 \mathrm{wt} . \%$ and $2.5 \mathrm{wt} . \%$ of clay is the highest result and the closest values. While adding $2.5 \mathrm{wt} . \%$ and $4 \mathrm{wt} . \%$ of clay, significant and steep reduction of the volume resistivity depicted. In case of XLPE/ $\mathrm{SiO}_{2}$, one can find the best values of the volume resistivity at injection with $2.5 \mathrm{wt} . \%$ silicon dioxide. The injection with clay showed significant improvement of cable electrical properties in contrast with the modification by $\mathrm{SiO}_{2}$. The modified clay rate of changes in volume resistivity is slower than $\mathrm{SiO}_{2}$ injected one.

Indeed, analytical calculations are the initial step of any system validation, for instance the insulation resistance of the modified cable is given by

$$
R=\frac{\left(3.66 \cdot 10^{-7}\right) \cdot V R \cdot A}{t}
$$

where $R$ is insulation resistance, $V R$ is volume resistivity, $A$ is cross section area, and $\mathrm{t}$ is thickness. The calculated results of the modified cable insulation resistance according to eqn. 1 that is shown in Fig. 9 fully meet the agreement pattern of the measured results in Fig. 8. Concentration of $2.5 \mathrm{wt} . \%$ of clay and $\mathrm{SiO}_{2}$ nanomaterials will promote the highest insulation resistance enhancement. However, the increasing of the mixed nanomaterials augments the insulation resistance up to around $5 \mathrm{wt} . \%$ $[26,27]$. This work experimentally optimizes the percentage added value of the nanomaterial that can improve the electrical properties. The additive percentage of 2.5 wt.\% can be

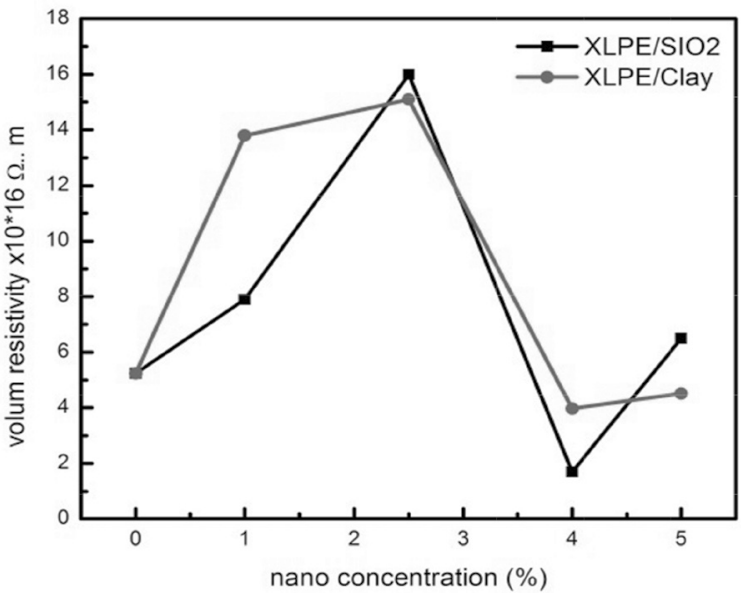

Figure 8 Histogram illustrates the comparison between volume resistivity of XLPE modified with $\mathrm{SiO}_{2}$ nanofiller and XLPE modified with clay nanofiller

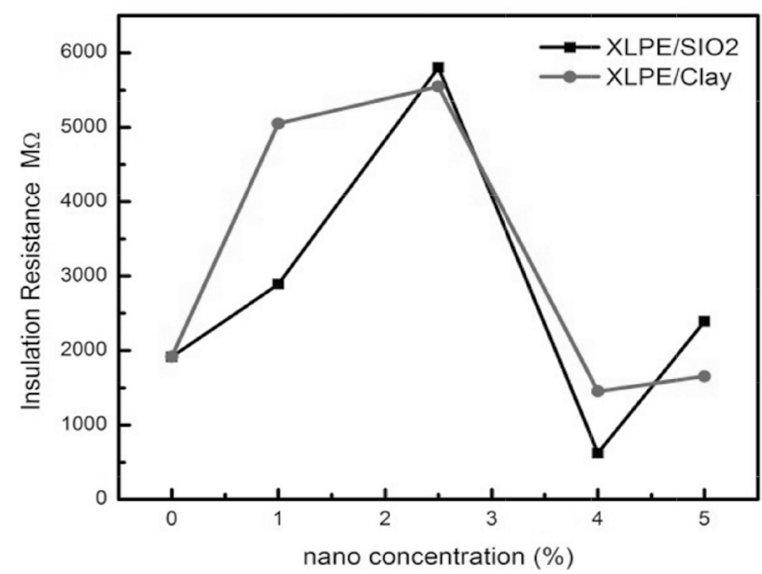

Figure 9 Histogram illustrates the comparison between insulation resistance of XLPE modified with $\mathrm{SiO}_{2}$ nanofiller and XLPE modified with clay nanofiller

considered the optimized value in contrast with both the nanomaterial cost and the cable properties with improved insulation resistance $5800 \mathrm{M} \Omega$ for $\mathrm{XLPE} / \mathrm{SiO}_{2}$ and $5549 \mathrm{M} \Omega$ for XLPE/clay while the pure XLPE cable was $1800 \mathrm{M} \Omega$. Furthermore, volume resistivity augmentation grants higher breakdown voltage of the modified XLPE cable to meet wide range of applications such as both medium and high voltages [28].

\section{Electric Capacitance and Dielectric constant}

During the limited proportional bound, the addition of nanofillers to cable insulation can cause capacity increase according to Figure 


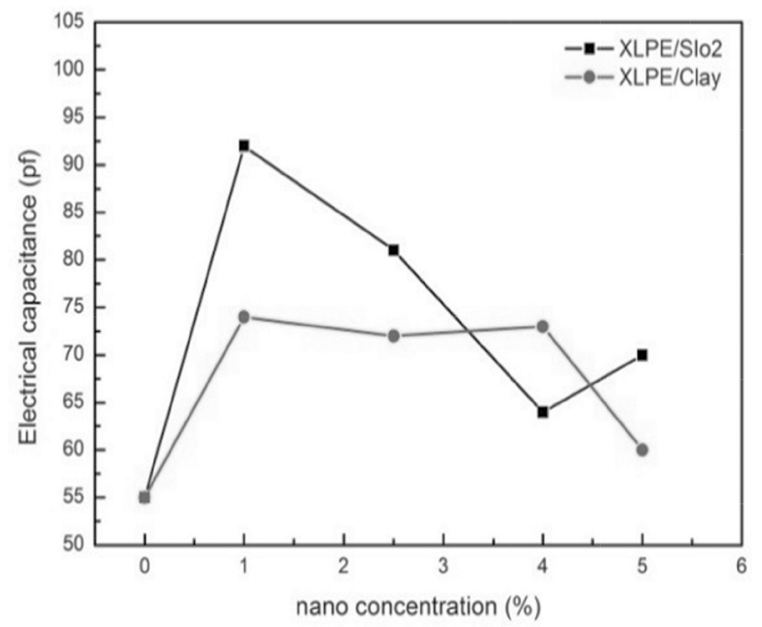

Figure 10 Histogram illustrates the comparison between electric capacitance of XLPE modified with $\mathrm{SiO}_{2}$ nanofiller and XLPE modified with clay nanofiller

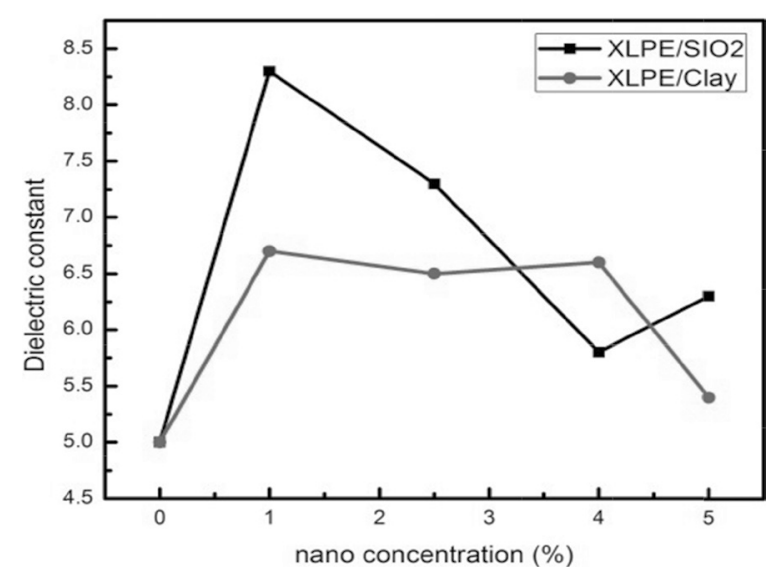

Figure 11 Histogram illustrates the comparison between dielectric constant of XLPE modified with $\mathrm{SiO}_{2}$ nanofiller and XLPE modified with clay nanofiller

10, which illustrates significant increase in the electric capacitance for $\mathrm{XLPE} / \mathrm{SiO}_{2}$ cable insulator with nanofillers concentration of $1 \%$ to 87 Pico Farad ( $\mathrm{pF}$ ) than other nanofiller concentrations (2.5\% and $4 \%$ ), compared with zero \% filling concentration (unfilled cable/ $\mathrm{XLPE}$ ) of $50 \mathrm{pF}$. In addition, there was increase in electric capacitance for XLPE/clay cable insulator with nanofillers concentration of $1 \%$ to $69 \mathrm{pF}$, than other nanofiller concentrations (2.5\% and $4 \%)$, compared with zero \% filling concentration (unfilled cable/XLPE) of $50 \mathrm{pF}$.

It was concluded that there was a significant improvement of electric capacitance according to nanofillers concentration of $1 \%$ by XLPE/ $\mathrm{SiO}_{2}$ than different concentrations of XLPE/clay, and other concentration ( $2.5 \%$ and $4 \%$ ) of XLPE/
$\mathrm{SiO}_{2}$, and zero\% filling concentration (unfilled cable/XLPE) of $50 \mathrm{pF}$.

Significant authenticity has been depicted and proved by the dielectric measurement results in (Figure 11), where they have the same pattern of the capacitance results in (Figure 10).

\section{Mechanical Measurements}

The mechanical properties of neat XLPE and modified cables with nanocomposites, the results shown in Figs. 12 and 13 can be summarized as follows:

a) both $\mathrm{XLPE} / \mathrm{SiO}_{2}$ and XLPE/Clay nanocomposites of $4 \%$ offer better tensile strength values of $18 \mathrm{~N} / \mathrm{mm}^{2}$ and $17 \mathrm{~N} / \mathrm{mm}^{2}$ respectively compared to $15 \mathrm{~N} / \mathrm{mm}^{2}$ for XLPE;

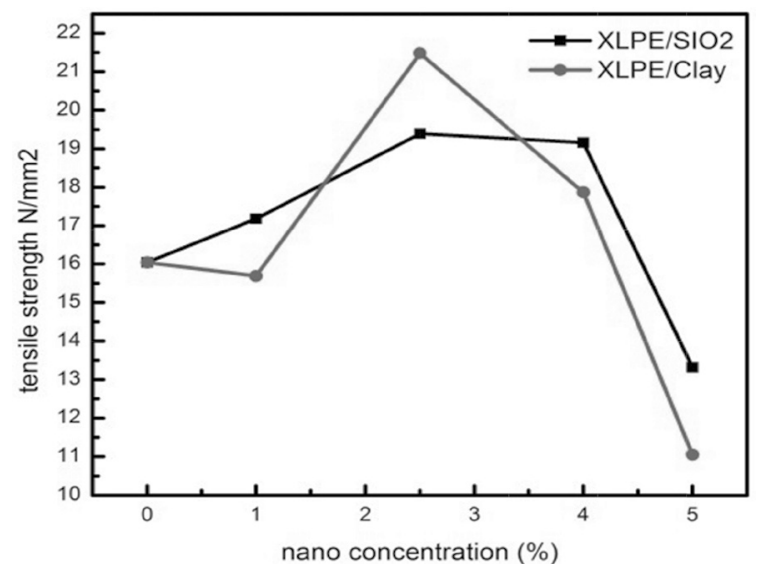

Figure 12 Histogram illustrates the comparison between tensile strength of XLPE modified with $\mathrm{SiO}_{2}$ nanofiller and XLPE modified with clay nanofiller

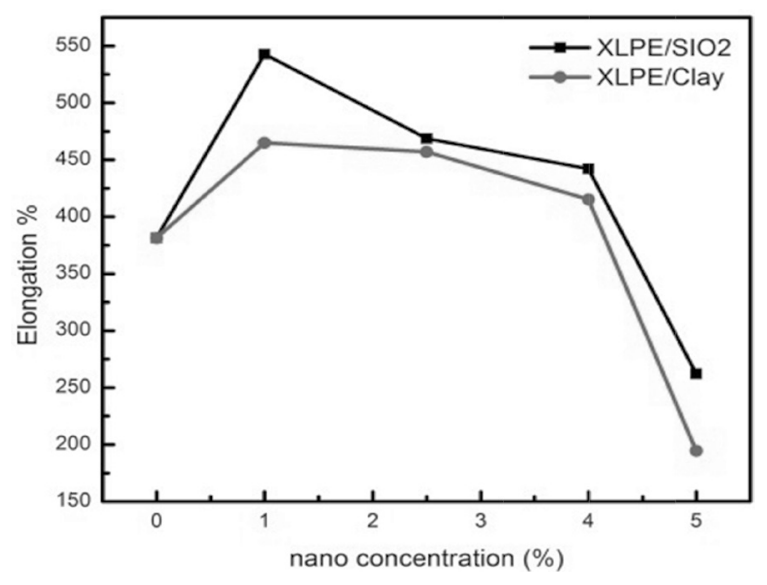

Figure 13 Histogram illustrates the comparison between elongation of XLPE modified with $\mathrm{SiO}_{2}$ nanofiller and XLPE modified with clay nanofiller 
b) furthermore, $\mathrm{XLPE} / \mathrm{SiO}_{2}$ shows enhanced properties for all mechanical characteristics; tensile strength and elongation in comparison with clay fillers;

c) although the mechanical characteristics are improved at $4 \%$ nanofiller, this work depicts much more improvement at $2.5 \% \mathrm{XLPE} / \mathrm{SiO}_{2}$ and XLPE/Clay, offering better tensile strength values of $21 \mathrm{~N} / \mathrm{mm}^{2}$ and $19 \mathrm{~N} / \mathrm{mm}^{2}$ respectively.

In both $\mathrm{XLPE} / \mathrm{SiO}_{2}$ and XLPE/clay nanocomposites, the elongation improvement is directly proportional to the filler concentration such as avoiding aggregation condition.

\section{Conclusions}

Nanofillers $\left(\mathrm{SiO}_{2}\right.$ and clay) were evaluated in this work to improve and extend lifetime of XLPE cable insulations by enhancing the electrical and mechanical properties. The results clearly illustrate that many electrical and mechanical properties were improved as volume resistivity, insulation resistance, electrical capacitance, dielectric constant, tensile strength, and elongation. $205 \%$ and $189 \%$ for volume resistivity and instance were improved for $\mathrm{XLPE} / \mathrm{SiO}_{2}$ and XLPE/clay respectively. Finally, we recommended using $1 \%$ concentration of $\mathrm{SiO}_{2}$ instead of other concentrations of clay nanofillers for some developments in polymeric cable insulation production.

\section{圓 Reference:}

1. York, Robert Jonathan, Joseph Benjamin Ulrich, Grant Murphy, and Daniel George Prather. (2015). Mitigation of aging in low voltage power cables in nuclear power plants.

2. IAEA 2018. Going long term: US nuclear power could extend operating life to 80 years. In search of extendable conditions for cable environmental qualification in nuclear power plants. Journal of Nuclear Science and Technology. 53.11, pp. 1735-1741.

3. Yaacob, M. M., Kamaruddin, N., Mazlan, N. A., Noramat, N. F., Aman, A., Alsaedi, M. A. (2012). Electrical characteristics of polyvinyl chloride with wollastonite filler for high voltage outdoor insulation material. Jurnal Teknologi, 64, No. 4.

4. Sharma, A. L., Awalendra K. Thakur. (2010). Improvement in voltage, thermal, mechanical stability and ion transport properties in polymer-clay nanocomposites. Journal of applied polymer science. 118, No. 5, pp. 2743-2753.

5. Pleşa, Ilona, et al. (2016). Properties of polymer composites used in high- $35^{*} 8789$ voltage applications. Polymers, 8.5, 173.

6. Fréchette, Michel F., Clive W. Reed. (2006). On molecular dielectrics in their role in shaping and controlling nanodielectrics. Electrical Insulation and Dielectric Phenomena, 2006 IEEE Conference, pp. 333-337.

7. Nelson, J.K. (2010). Background, principles and promise of nanodielectrics. In Dielectric Polymer Nanocomposites, Springer, New York, USA, pp. 1-30

8. Pleşa, Ilona, et al. (2016). Properties of polymer composites used in high-voltage applications. Polymers, 8.5, 173.

9. Tanaka, T., Montanari, G.C., Mülhaupt, R. (2004). Polymer nanocomposites as dielectrics and electrical insulation. Perspectives for processing technologies, material characterization and future applications, IEEE Trans. Dielectr. Electr. Insul. 11, pp. 763-784.

10. Tanaka, T., Bulinski, A., Castellon, J., Frechette, M., Gubanski, S., Kindersberger, J., Montanari, G.C., Nagao, M., Morshuis, P., Tanaka, Y., et al. (2011). Dielectric properties of XLPE/SiO2 nanocomposites based on CIGRE WG D1.24 cooperative test results. IEEE Trans. Dielectr. Electr. Insul. 18, pp. 1482-1517.

11. S. Peng, J. He, J. Hu, X. Huang, Jiang, P. (2015). Influence of functionalized $\mathrm{MgO}$ nanoparticles on electrical properties of polyethylene nanocomposites. IEEE Trans. Dielectr. Electr. Insul., V. 22, No. 3, pp. $1512-1519$.

12. Roy, M., Nelson, J.K., MacCrone, R.K., Schadler, L.S., Reed, C.W., Keefe, R. (2005). Polymer nanocomposite dielectrics - the role of the interface. IEEE Trans. Dielectr. Electr. Insul., 12, pp. 629-643,

13. Khodaparast, P., Ounaies, Z. (2013). On the impact of functionalization and thermal treatment on dielectric behavior of low content TiO2/ PVDF nanocomposites. IEEE Trans. Dielectr. Electr. Insul., V. 120, No. 1, pp. 166-176.

14. Gonzalez, N., Custal, M. D., Lalaouna, A., Riba, J., Armelin, E. (2016). Improvement of dielectric properties of natural rubber by adding perovskite nanoparticles. European Polymer Journal, V. 75, pp. 210-222.

15. Przybytniak, G., J. Boguski, V. Placek, L. Verardi, D. Fabiani, Erik Linde, and Ulf W. Gedde. (2015). Inverse effect in simultaneous thermal and radiation aging of EVA insulation. Express Polymer Letters, 9, No. 4.

16. Nelson J. K. and Fothergill J.C. (2004). Internal charge behavior in nanocomposites. Nanotechnology, V. 15, No. 5, pp. 586-595.

17. Fothergill, J. C. (2007). Ageing, space charge and nanodielectrics: Ten things we don't know about 
dielectrics. IEEE International Conference on Solid Dielectrics, Winchester, pp. 1-10.

18. Yan, Long, Zhisheng $\mathrm{Xu}$, and Xinghua Wang. (2017). Influence of nano-silica on the flame retardancy and smoke suppression properties of transparent intumescent fire-retardant coatings. Progress in Organic Coatings, 112, pp. 319-329.

19. Wei, Ping, et al. (2006). Synergistic flame retardant effect of SiO2in LLDPE/EVA/ATH blends. Journal of fire sciences, 24.6, pp. 487-498.

20. Tai Q, Yuen RKK, Song L, Hu Y. (2012). A novel polymeric flame retardant and exfoliated clay nanocomposites: Preparation and properties. Chemical Engineering Journal, 183, 542.

21. $\mathrm{Hu}$, Yuan, et al. (2014). Polymer/layered compound nanocomposites: a way to improve fire safety of polymeric materials. Fire Safety Science, 11, pp. 66-82.

22. Moisala, A., Li, Q., Kinloch, I. A., Windle, A. H. (2006). Thermal and electrical conductivity of singleand multi-walled carbon nanotubeepoxy composites. Composites Science and Technology, 66, pp. 1285-1288.

23. Chunyang Li, Hong Zhao, Hui Zhang, Ying Wang. (2018). The role of inserted polymers in polymeric insulation materials: insights from QM/MD simulations. Springer-Verlag GmbH Germany, part of Springer Nature.

24. Jayanthi, P., Pugazhendhi Sugumaran, C. (2013). Analysis on electrical and mechanical properties of cable insulation with nano composites. Department of High Voltage Engineering, College of Engineering Guindy, India.

25. Thenthiruppathi, T., Harish, R.K., Ramkumar R. (2014). Analysis on Dielectric and Mechanical Properties of Power Cable with Nano Composites. Teaching Fellow, Department of Electrical \& Electronics Engineering, India.

26. Tai Q, Yuen RKK, Song L, Hu Y. (2012). A novel polymeric flame retardant and exfoliated clay nanocomposites: preparation and properties. Chemical Engineering Journal, 183, 542.

27. Ahmed Dabbak, Sameh, et al. (2018). Electrical properties of polyethylene/polypropylene compounds for high-voltage insulation. Energies. 11.6, pp. 1448.

\section{Модифікація характеристик ізоляції кабелів для AEC з використанням нанокомпозитів}

Ель-Сайед Соліман А. Саїд1', Ель Саїд Абдул Ель-Азіз Отман', Мохамед Реда Эзз-Элдин ${ }^{2}$, Хавайда Галал А.М Taха²., Валаа Абд-Елмонем Ель-Каттан ${ }^{2}$

1 Кафедра електротехніки Інженерного факультету Університету Аль-Азхар, Каїр, Єгипет

2 Єзипетський орган ядерного та радіачійного регулювання (ENNRA), Kaїр, Єzunem

На сьогоднішній день термін експлуатачії атомних електростанцій (AEC) може бути продовжений до 80 років. Це дозволяє рекомендувати модифікацію деяких властивостей ізолячії із просторово-зшитого поліетилену (XLPE). Ця робота представлявляє собою лабораторну версію нанонаповнювачів з кремнезему $\left(\mathrm{SiO}_{2}\right)$ та глини для посилення ізолячії кабелів. Випробувано та виміряно об'ємний опір, ємність, діелектричні втрати, міцність при розтягуванні та відносне подовження нанорозмірних зразків. Окрім того, вимірювання були проведені для модифікованих зразків складу $\mathrm{XLPE}_{\mathrm{SiO}}$ і XLPE/глина при адитивній концентрації 1, 2, 5, 4 і 5 масових відсотків (мас. \%). Офіційно задокументовані результати засвідчили набагато кращу електроізолячію кабелів та підвищені фізико-механічні властивості. Об'ємний опір поліпшився до $205 \%$ і 189 \% відповідно для зразків складу XLPE/SiO 2 ma XLPE/глина. Аналітичні розрахунки узгоджуються з експериментальними результатами.

Ключов і слова: XLPE, нанонаповнювачі, ізолячія кабелів, електричні та механічні властивості.

\section{Модификация характеристик кабельной изоляции для АЭС с использованием нано- композитов}

Эль-Сайед Солиман А. Саид ${ }^{1}$, Эль Саид Абдул Эль
Азиз Отман', Мохамед Реда Эзз-Элдин ${ }^{2}$, Ховайда
Галал А.М Таха", Валаа Абд-Эльмонем Эль-Каттан ${ }^{2}$,

1 Кафедра электротехники Инженерного факультета Университета Аль-Азхар, Каир, Египет

2 Египетский орган ядерного и радиачионного регулирования (ENNRA), Kaup, Ezunem

В настоящее время срок службы атомных электростанций (АЭС) может быть продлен до 80 лет. Это позволяет рекомендовать модификацию некоторых свойств пространственно-сшитой полиэтиленовой (XLPE) кабельной изолячии. Эта работа представляет собой лабораторную версию нанонаполнителей в виде кремнезема $\left(\mathrm{SiO}_{2}\right)$ и глины для усиления изолячии кабелей. Проведены испытания и измерения объемного удельного сопротивления, емкости, диэлектрических потерь, прочности на растяжение и относительного удлинения наноразмерных образиов. Кроме того, измерения были выполнены для модифицированных образцов состава XLPE/ $\mathrm{SiO}_{2}$ и XLPE/глина с аддитивной концентрачией 1, 2.5, 4 и 5 массовых прочентов (мас.\%). Офичиально задокументированные результаты засвидетельствовали намного лучшую электрическую изолячию и повышенные физикомеханические свойства кабелей. Объемное сопротивление улучшилось до $205 \%$ и 189 \% соответственно для образчов состава XLPE/SiO 2 и XLPE/глина. Аналитические расчеты согласовываются с экспериментальными результатами.

Ключев в е слов а: XLPE, нанонаполнители, изоляция кабелей, электрические и механические свойства. 